\title{
白菜の成分に關する研究 (第五報) ベンタぬチルーアンペロプチンのアルカリによる分解に就て
}

(炤和十四年五月サ三日受領)

久保田少志

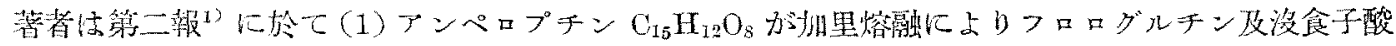

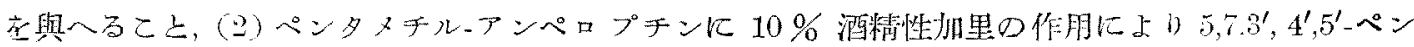

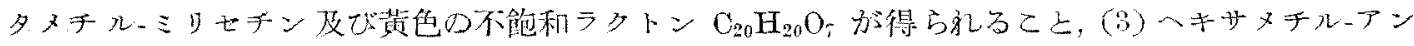

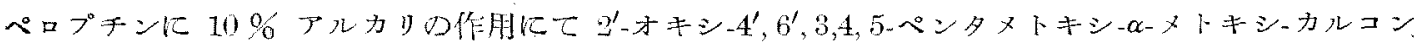

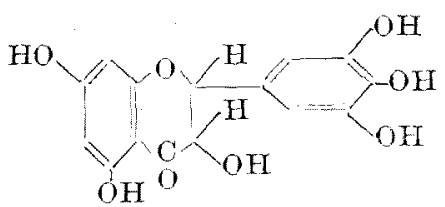

(1)

アンペロプチン が得ら礼ること算老主なる理山上して、アンペロプチンに(1) 式在提出した。

斯樣なとドロフラボノール型つ化合物が自然界に浸兒され

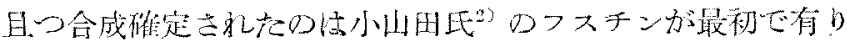

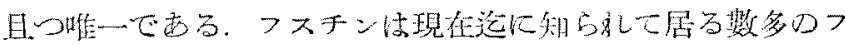

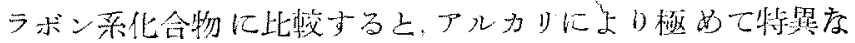

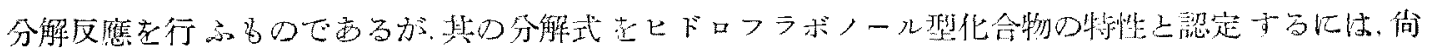

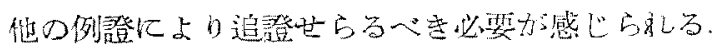

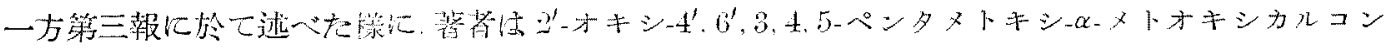

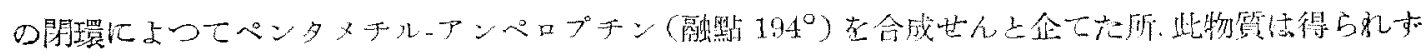

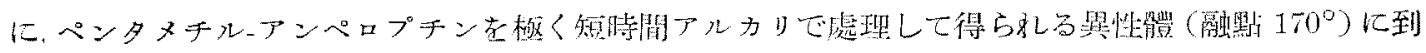

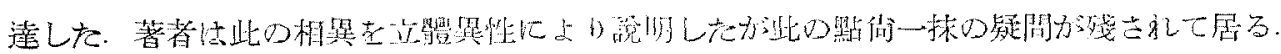

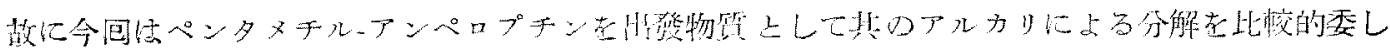

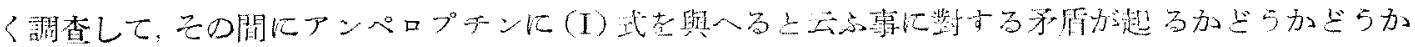
上王心ことを敬察した。

先づヘンタタチルーアンペロプチン (II) 在 $10 \%$ ×タノール

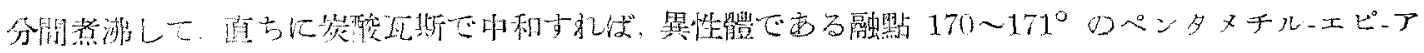

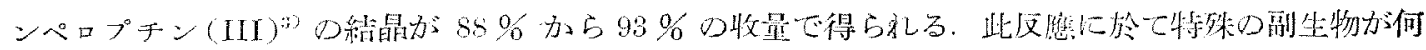

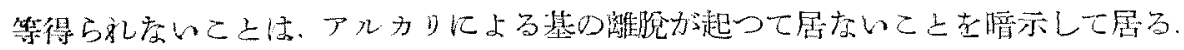

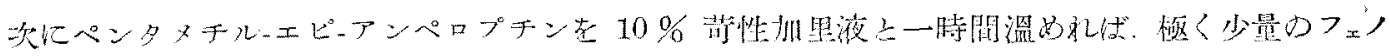

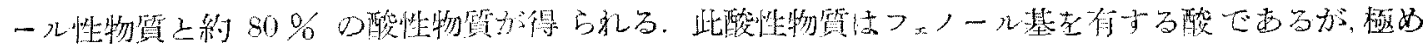

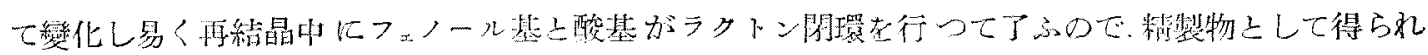

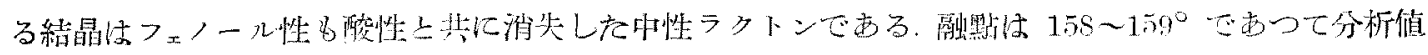

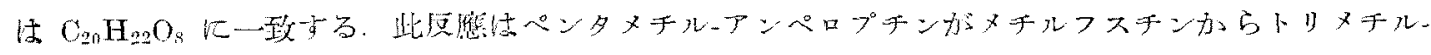

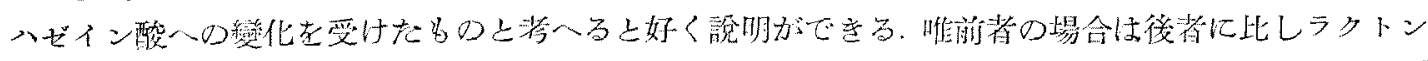

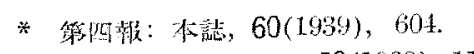

755. 3) 久保日1: 不誌, $59(1938), 1160$.
2) 小喵：本誌，55(14:34), 


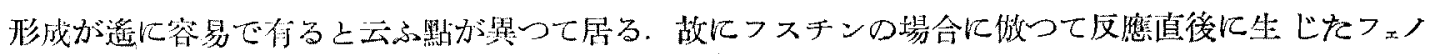

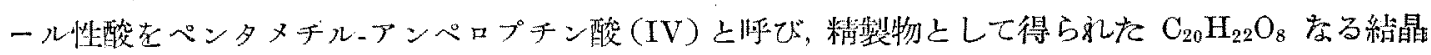

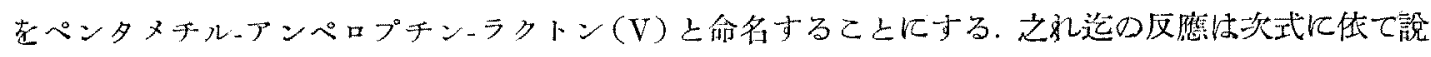
明さ礼る。<smiles>COc1cc(OC)c2c(c1)O[C@H]([C@H](C)O)[C@H](O)[C@H]2OC</smiles>

(II) $\mathrm{C}_{20} \mathrm{H}_{22} \mathrm{O}_{3}$, 融點 $194^{\circ}$ ペンタメチルーアンペロプチン<smiles>COc1cc(O)c(C=O)c(OC)c1</smiles><smiles>COC1=CC(COC(=O)c2c(O)cc(OC)cc2OC)C(OC)C=C1OC</smiles><smiles>COC=C(OC)C(=CC=CC1(O)C(=O)Oc2cc(OC)cc(OC)c21)OC</smiles>

(V) $\mathrm{C}_{20} \mathrm{H}_{22} \mathrm{O}_{8}$, 融點 $158 \sim 159^{\circ}$ ペンタメチルーアンペロブチンーラタトン<smiles>COc1cc(OC)c2c(c1)OC(O)C(O)C2c1cc(OC)c(OC)cc1OC</smiles>

(III) $\mathrm{C}_{20} \mathrm{H}_{22} \mathrm{O}_{8}$, 融默 $170^{\circ}$ ペンタメチルーェピーアンペロプチン<smiles>COc1cc(O)c(Cl)c(C(O)=C(O)c2cc(OC)c(OC)c(OC)c2)c1</smiles><smiles>COc1cc(O)c(C(O)(C(=O)O)C(O)c2cc(OC)c(OC)c(OC)c2)c(OC)c1</smiles>

(IV) $\mathrm{C}_{20} \mathrm{H}_{24} \mathrm{O}_{9}$ ペンタメチルーアンペロプチン酸<smiles></smiles>

(VI) $\mathrm{C}_{26} \mathrm{H}_{20} \mathrm{O}_{7}$, 融點 162 163 アンヒドローペンタメチルーアンペロプチンーラタトン

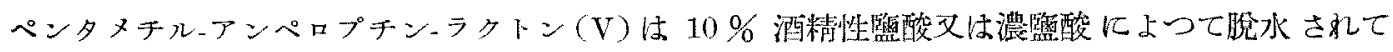

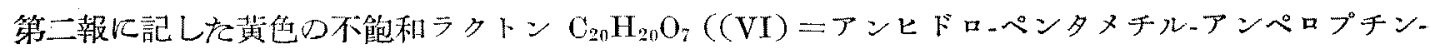

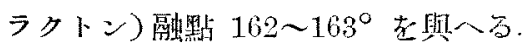

次に上記の妇くペンタメチルーアンペロプチン酸は容易にラタトン閉環を行ふため純桲に單離する

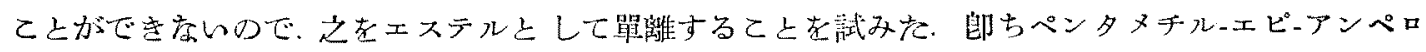

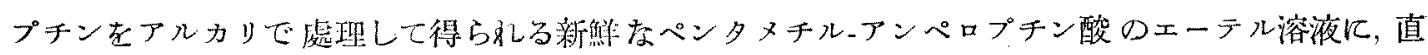

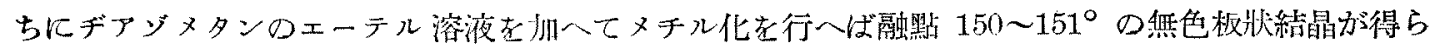

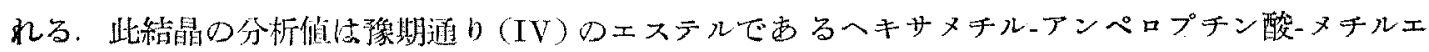
ステル(VII) $\mathrm{C}_{22} \mathrm{H}_{28} \mathrm{O}_{9}$ に一致し.フェノール性も酸性む缺如して居る. 又之れがェステルであるとと 


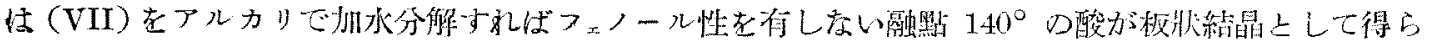
れることによりてb明膫である。此酸死へキサメチルーアンペロプチン酸(VIII) と㭔ぶこ上にする.

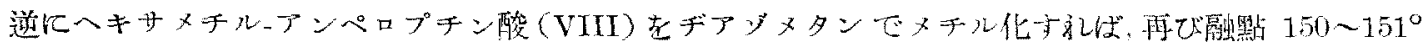

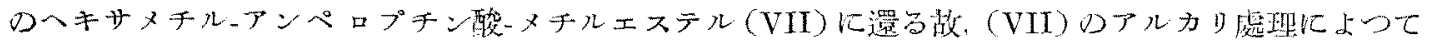

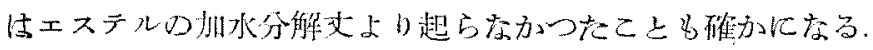

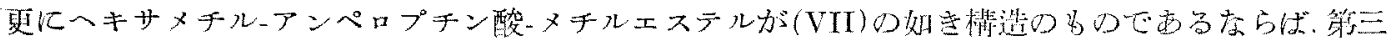

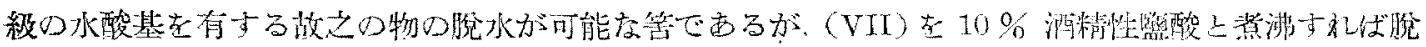

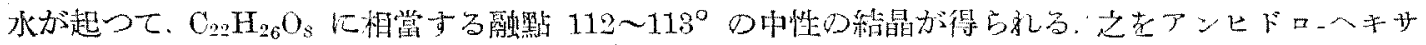

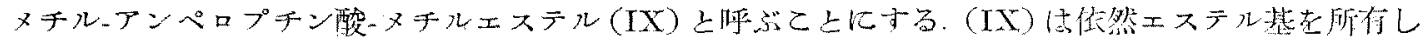

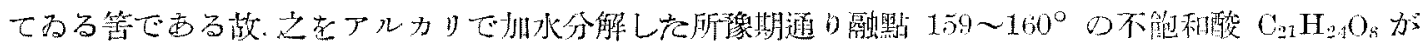

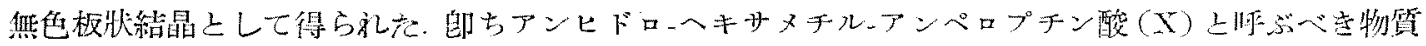

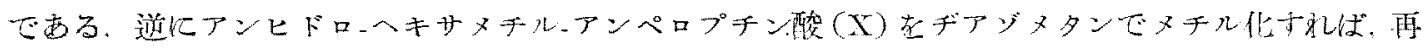

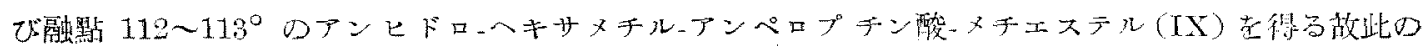

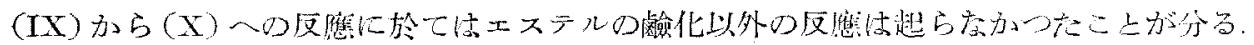

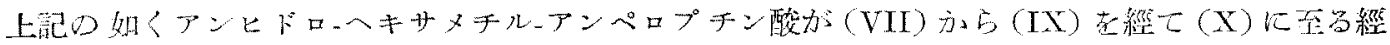

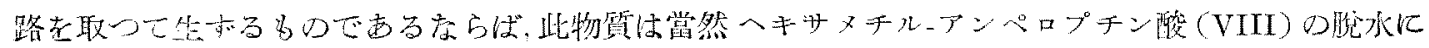

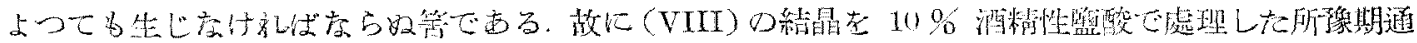

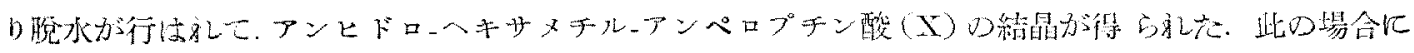

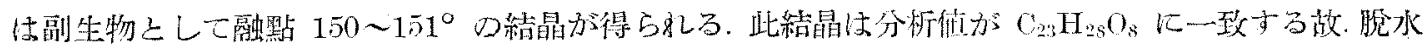<smiles>COc1cc(O)c(C(O)(O)C(O)(O)c2cc(OC)c(OC)c(OC)c2)c(OC)c1</smiles>

(IV) $\mathrm{C}_{20} \mathrm{H}_{24} \mathrm{O}_{9}$ ヘンタメチルーアンペロプチン酸

$\mathrm{H}_{3} \mathrm{CO}$<smiles>CC=CCOC(=O)C(O)(Cc1cc(OC)cc(OC)c1OC)C(=O)OC</smiles>

(VIII) $\mathrm{C}_{21} \mathrm{H}_{26} \mathrm{O}_{9}$, 触點 $140^{\circ}$ ヘキサメチルーアンペロプチン酸

$\mathrm{H}_{3} \mathrm{CO}$<smiles>COc1cc(C)cc(OC)c1C(=O)C(C)CC1CC(OC)C(OC)C(OC)C1</smiles>

(XI) $\mathrm{C}_{23} \mathrm{H}_{23} \mathrm{O}_{8}$, 融點 $150 \sim 151^{\circ}$ アンヒドローーキサメチルーアン ペロプチン酸・チルェステル

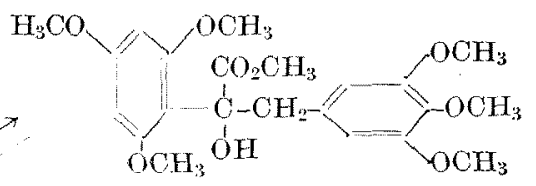

(VII) $\mathrm{C}_{22} \mathrm{H}_{99} \mathrm{O}_{9}$, 陆繁 $150 \sim 151^{\circ}$

へキサメチルーアンペロプテン酸ーメチルエステル $\downarrow_{\mathrm{C}} \mathrm{H}_{\tilde{\sigma}} \mathrm{OH}-\mathrm{HCl}$

$80^{4}$

C.F5OH-HCl

(IX) $\mathrm{C}_{22} \mathrm{H}_{26} \mathrm{O}_{8}$, 敔繁 $112 \sim 113^{\circ}$

アンヒドローでサメチルーアン

ペロプチン酸ーメチルェステル

CE: $: \uparrow / \mathrm{KOH}$<smiles>COC(=C=Cc1cc(OC)c(OC)c(OC)c1)c1c(OC)cc(OC)cc1OC</smiles>

(X) $\mathrm{C}_{2 \mathrm{I}} \mathrm{H}_{24} \mathrm{O}_{8}$, 融點 $159 \sim 160$

アンヒドローヘキサメチルーアンペロプチン酸 


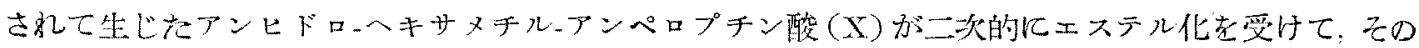

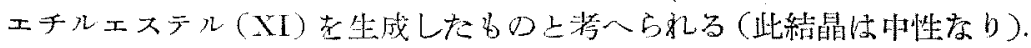

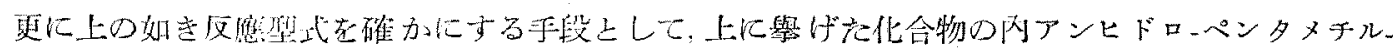

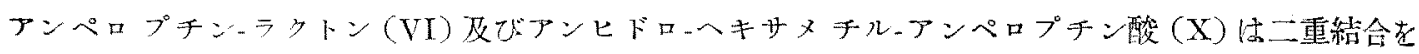

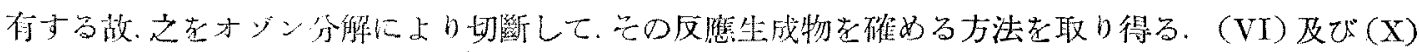

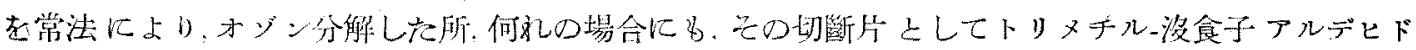

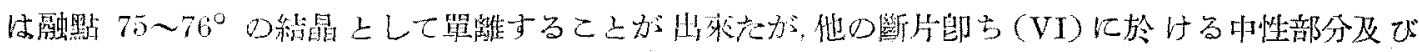

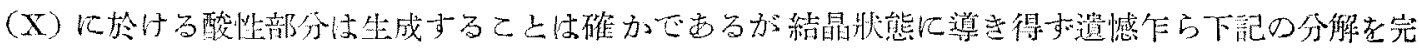

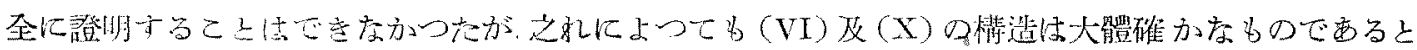
获一らしる。

$\mathrm{HaCO}$

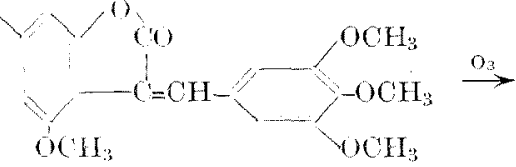

(YI)<smiles></smiles>

$\mathrm{OCH}_{3}$<smiles>COc1cc(C=O)cc(OC)c1OC</smiles>

㦚點 $75 \sim 76^{\circ}$

トリメチルー没金子アルデヒド

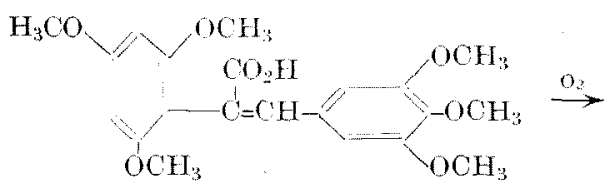

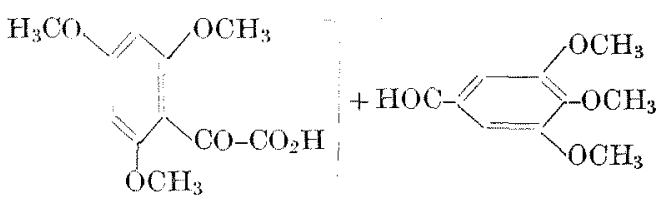

殿點 $75 \sim 76^{\circ}$

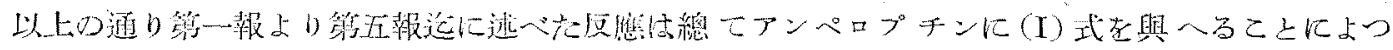

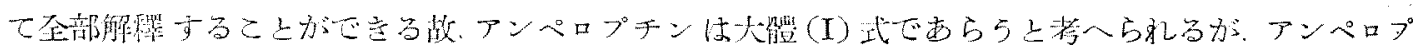

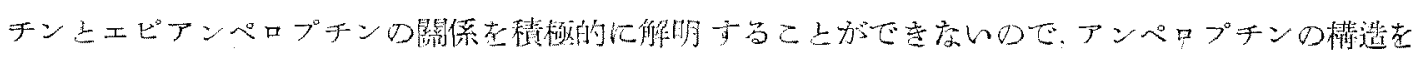

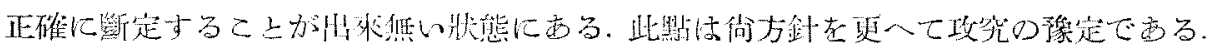

\section{實 驗 の 部}

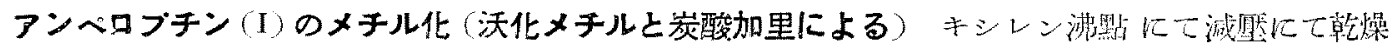

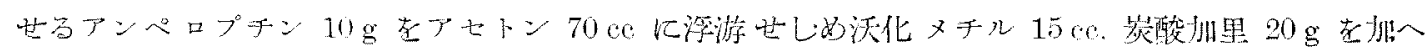

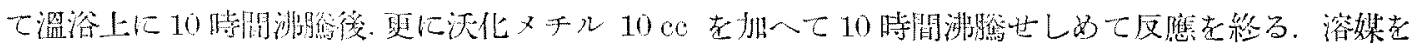

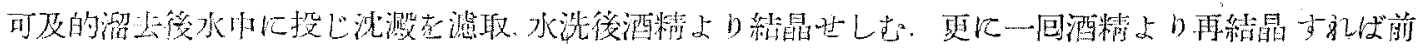

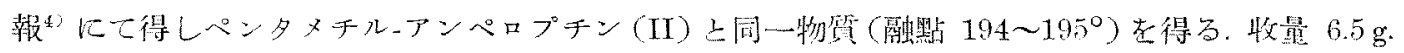

\section{ベンタメチル・エピーアンベロブチン (III) (ベンタメチル-アンベロブチン (II)に $10 \%$ アルカリ}

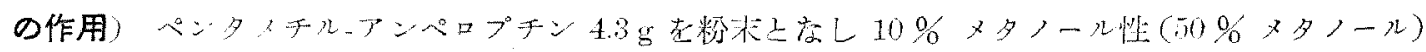

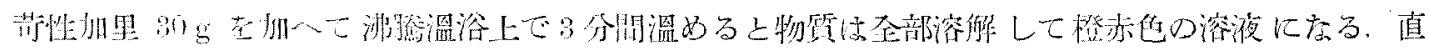

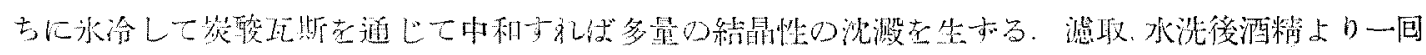

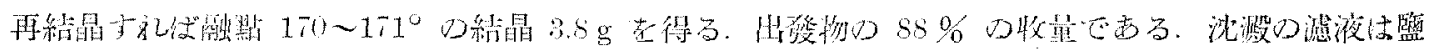

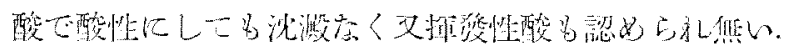

4) 久保目: 本竐, $59(1938), 105 \bar{i}$. 
ベンタメチルアンペロブチン-ラタトン（V)(ペンタメチル-エビ・アンペロプチンに $10 \%$ アルカリ

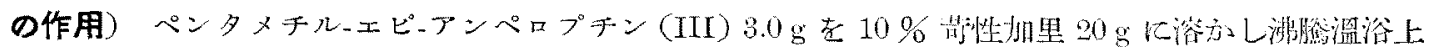

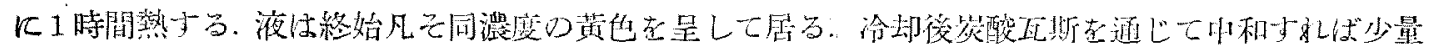

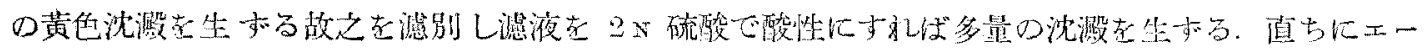

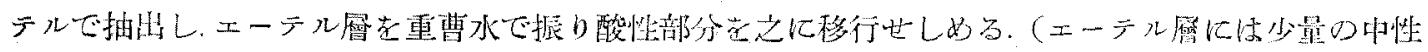

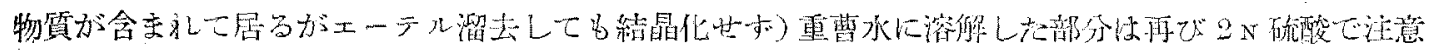

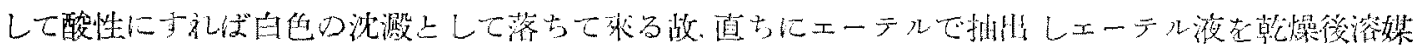

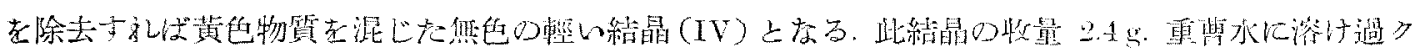

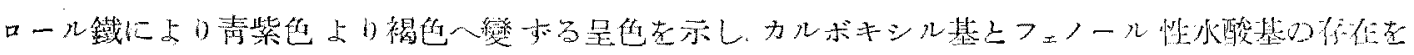

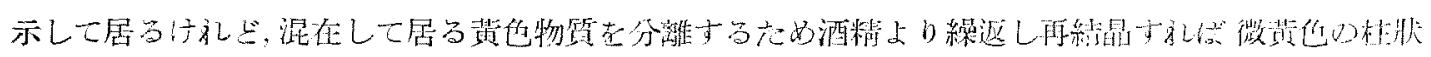

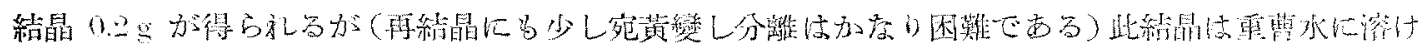

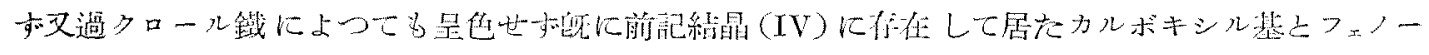

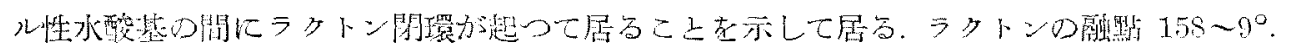

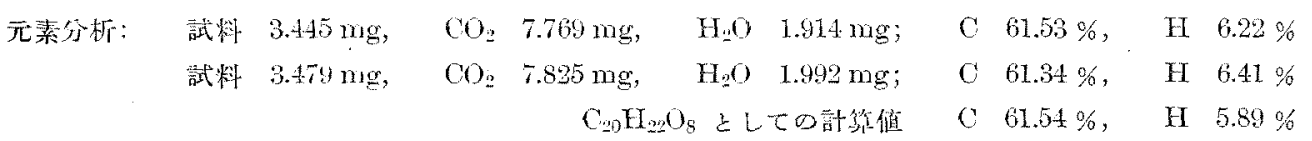

\section{ヘキサメチル-アンペロブチン酸-メチルエステル (VII)（ベンタメチル・アンベロブチン酸（IV）の}

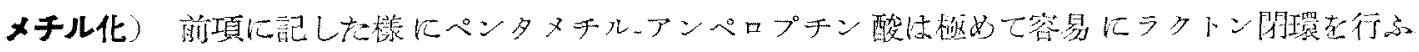

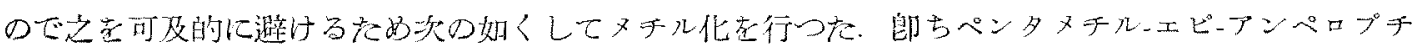

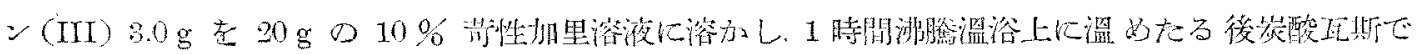

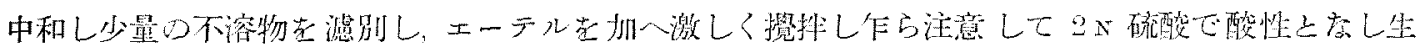

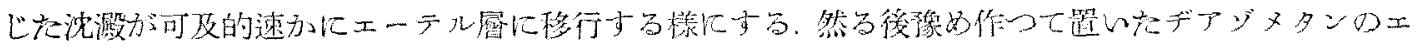

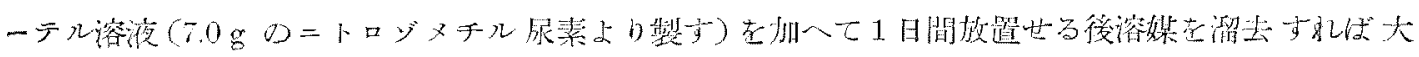

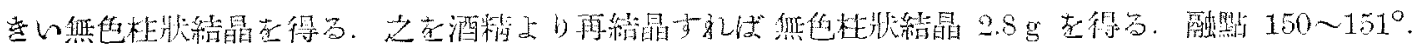

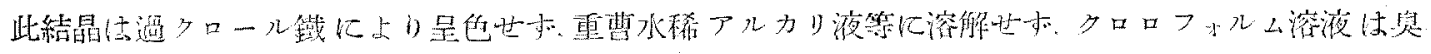

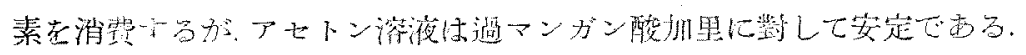

元素分析：

鼓帅

co

$\mathrm{H}_{2} \mathrm{O}$

$\mathrm{O}$

$\mathrm{H}$

$3.396 \mathrm{mg}$,
$3.58+\mathrm{ng}$,
$3.167 \mathrm{mg}$,
$3.656 \mathrm{mg}$,

$7 . \pm 76 \mathrm{mg}$

$1.960 \mathrm{nig} ;$

$61.11 \%$,

$6.57 \%$

!

$7.983 \mathrm{mg}$,

$2.291 \mathrm{mg}$ :

$60.72 \%$

$6.90 \%$

$7077 \mathrm{mg}$

$1.978 \mathrm{mg}$

$60.91 \%$,

$6.97 \%$

$8.140 \mathrm{mgg}$,

$2.158 \mathrm{mg}$

$60.72 \%$,

$6.59 \%$

$\mathrm{C}_{22} \mathrm{H}_{29} \mathrm{O}_{9}$ としてO計筫值

$60.55 \%$,

$6.4 \% \%$

ヘキサメチルーアンベロプチン酸 (VIII)(へキサメチル-アンベロ ブチン酸-メチルエステル(VII)

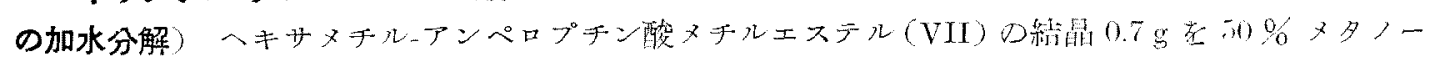

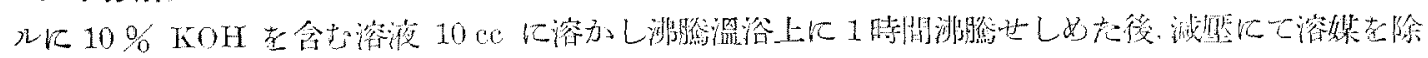

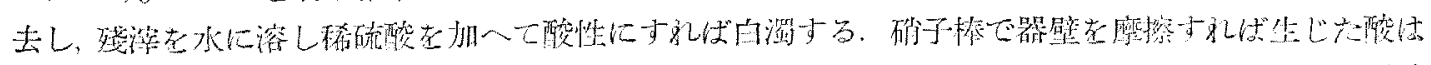

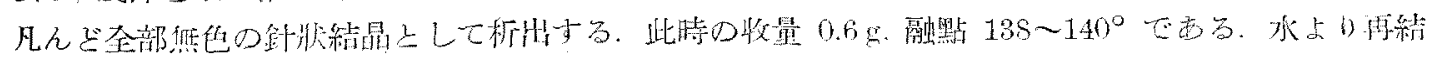

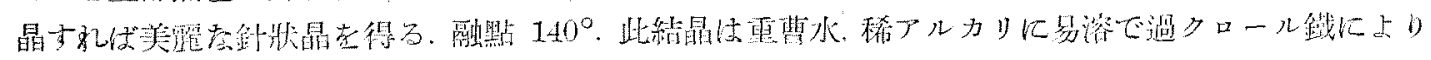

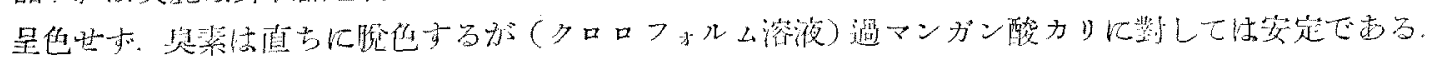




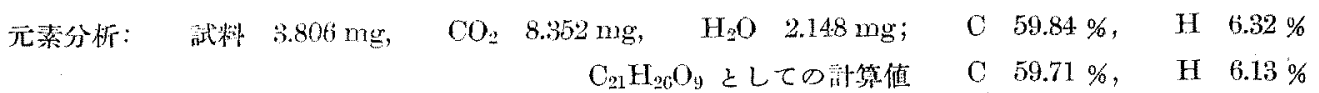

ヘキサメチル-アンベロブチン酸 (VII) のメチル化 上記の酸 (VIII)がメチル化により再び元の

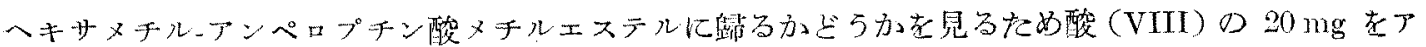

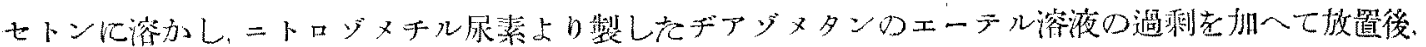

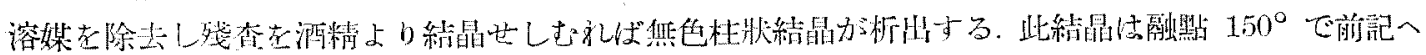

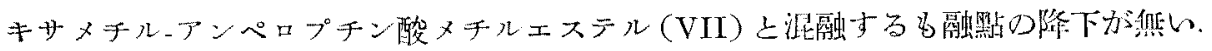

アンヒドロ-ヘキサメチル.アンヘロロブチン酸-メチルエステル (IX)（へキサメチル アンベロブチン 酸-メチルエステル(VII)の脫水) へキサメチルーアンペロプチン酸メチルェステル(VII) $2.5 \mathrm{~g}$ に酒

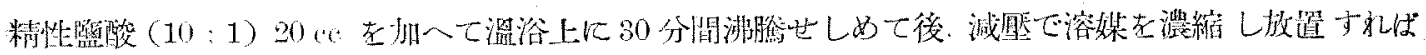

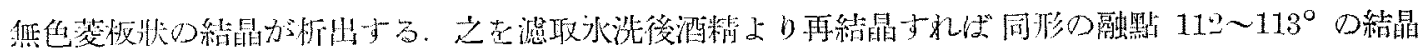

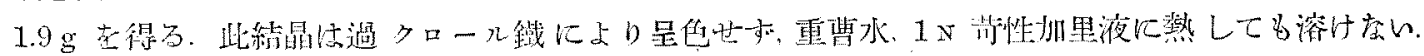

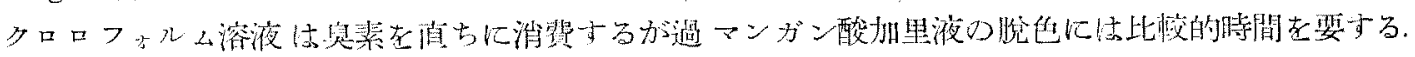

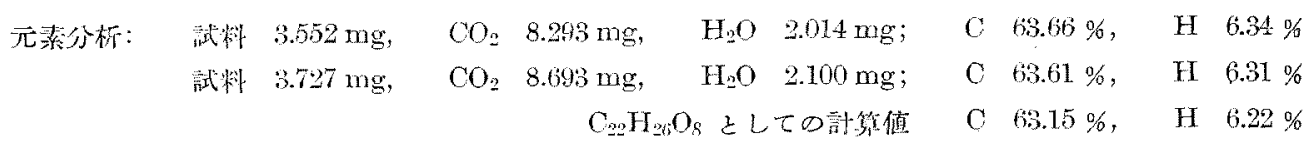

\section{アンヒドロ-ベンタメチル-アンブロブチン-ラクトン (VI) (ペンタメチル-アンベロプチン-ラクトン}

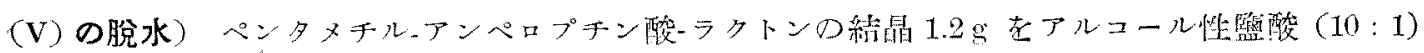

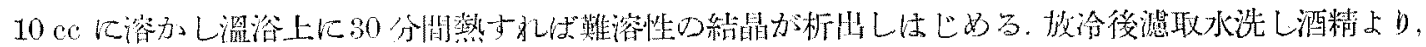

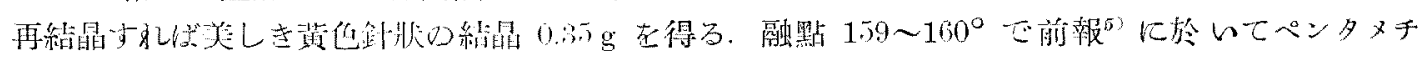

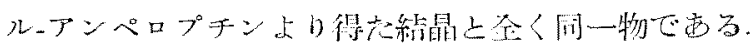

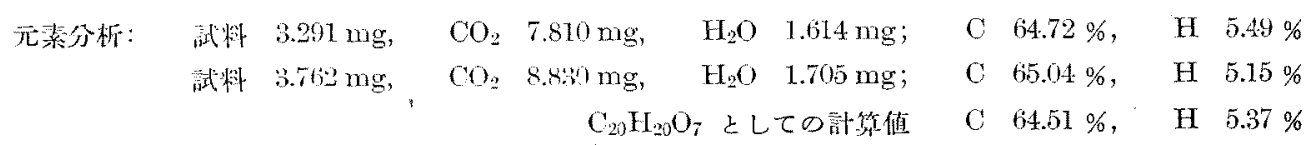

アンヒドロ・ヘキサメチル-アンベロブチン酸 $(\mathrm{X})$ (アンヒドロ-ヘキサメチル-アンベロブチン酸メ チルエステル (IX)の加水分解) アンヒドロ-へキサメチルーアンペロプチン酸-メチルェステル(VII)

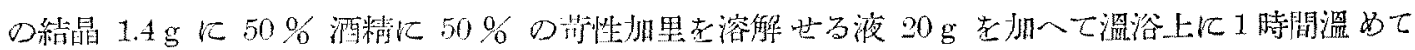

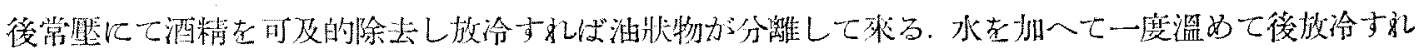

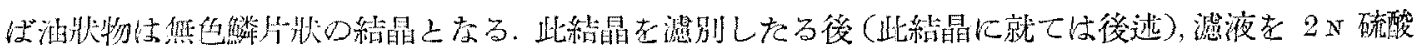

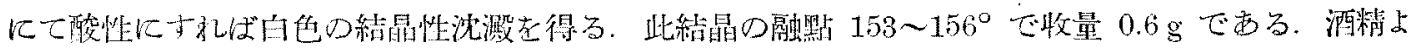

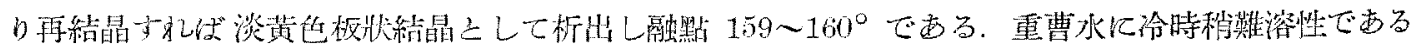

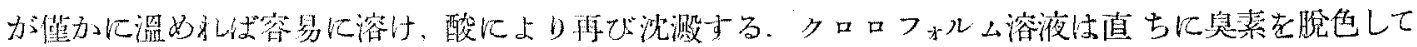

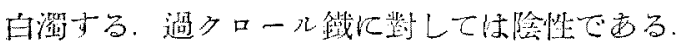

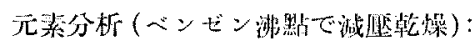
試料 $3.762 \mathrm{mg}$,
$\mathrm{CO}_{\mathrm{g}} \quad 8.632 \mathrm{mg}$,
$\mathrm{H}_{2} \mathrm{O} \quad 1.945 \mathrm{mg} ;$
C $62.57 \%$,
H $\quad 5.79 \%$
试料 $3.263 \mathrm{mg}$,
$\mathrm{CO}_{2} 7.524 \mathrm{mg}$,
$\mathrm{H}_{2} \mathrm{O} \quad 1.720 \mathrm{mg} ;$
C $62.88 \%$,
H $\quad 5.90 \%$
$\mathrm{C}_{21} \mathrm{H}_{24} \mathrm{O}_{8}$ としての計算值
C $62.38 \%$,
H $5.94 \%$

5) 久保四：本誌，59(1988), 1157. 


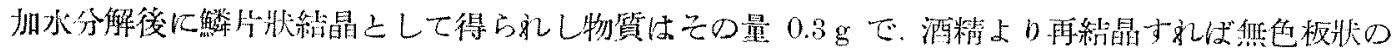

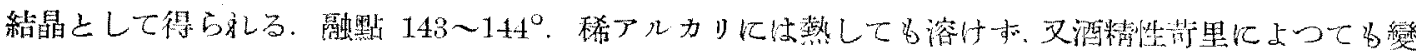

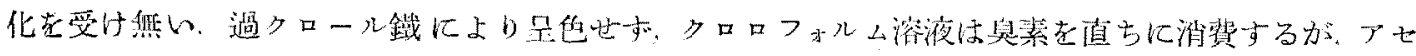

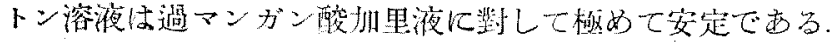

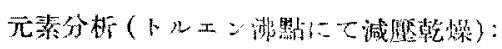

\begin{tabular}{|c|c|c|c|c|c|c|c|c|}
\hline $3.724 \mathrm{mg}$ & $\mathrm{CO}_{2}$ & $8.702 \mathrm{mg}$ & $\mathrm{H}_{2} \mathrm{O}$ & $2.174 \mathrm{mg}$; & $\mathrm{C}$ & $68.72 \%$ & $\mathrm{H}$ & $6.58 \%$ \\
\hline 期 $3.649 \mathrm{mg}$, & $\mathrm{CO}$ & $8.187 \mathrm{mg}$ & $\mathrm{H}_{2} \mathrm{O}$ & $2.198 \mathrm{mg}$ & C & $63.43 \%$ & $\mathrm{H}$ & \\
\hline
\end{tabular}

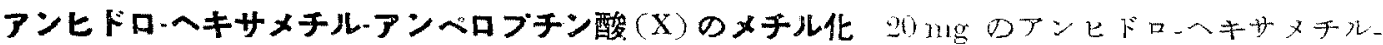

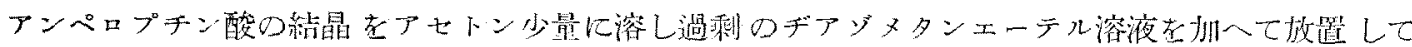

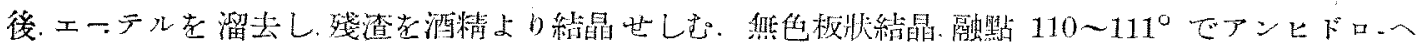

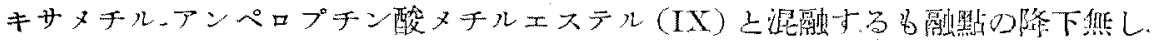

ヘキサメチル-アンベロブチン酸 (VIII) の脫水へキサメテル・アンペロプチン酸 (VIII) 融然 138

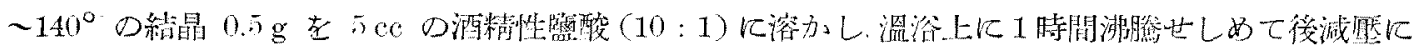

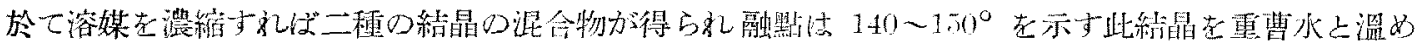

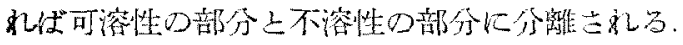

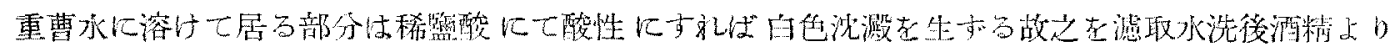

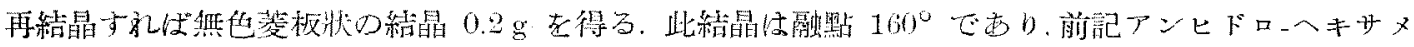

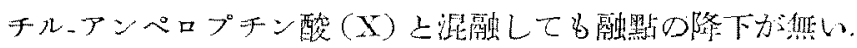

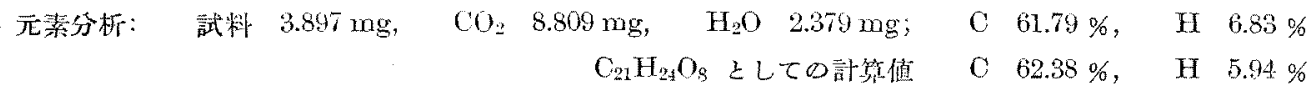

アンヒドロ・ヘキサメチルーアンペロブチン酸エチルエステル（XI）重曹水に不溶の部分は酒精よ

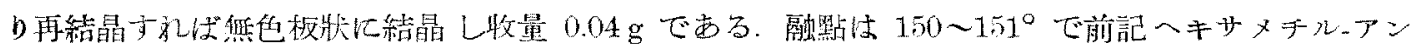

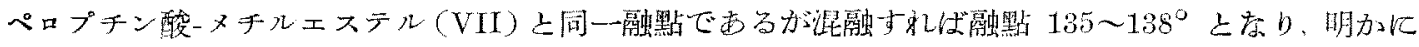

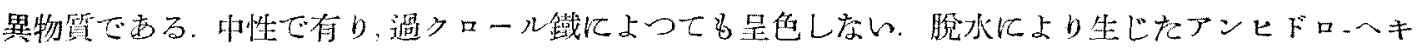

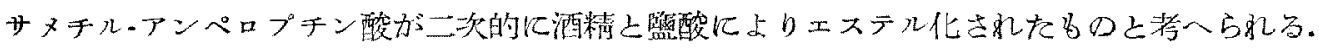

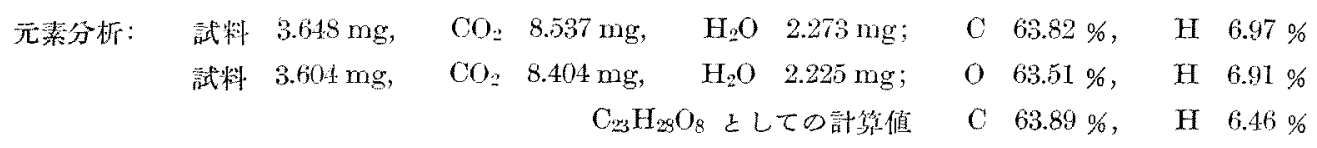

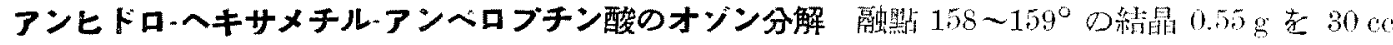

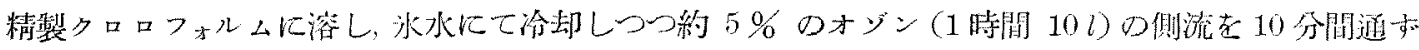

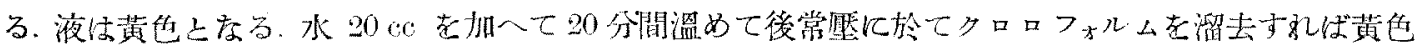

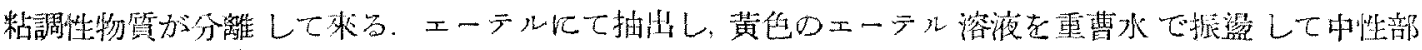

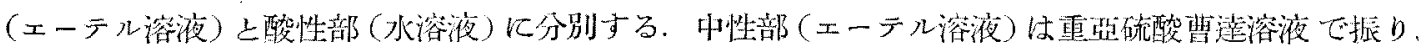

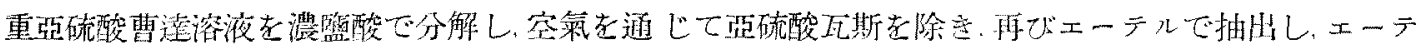

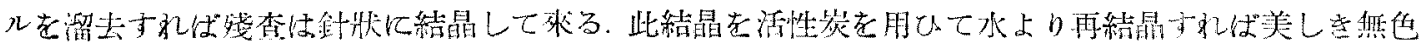

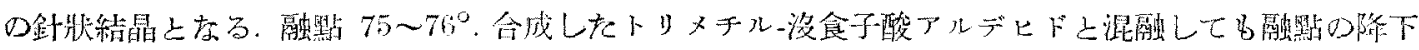
が呰い. 


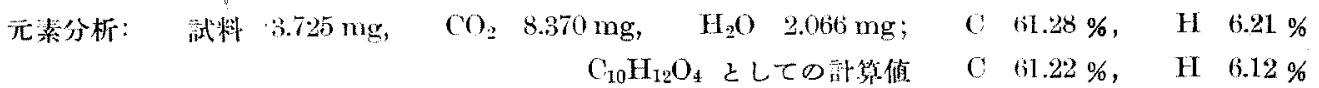

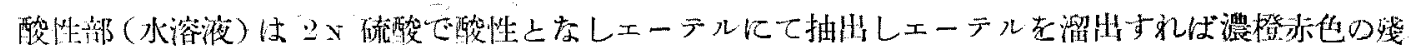
查在线し比物質は酸でするが遂に結晶化せしむるこ上不可能であつね。

アンヒドロペンタメチル-アンベロブチン-ラクトン (VI) のオン゙ン分解 アンヒドロ.ペンタヌチ

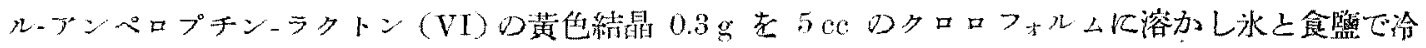

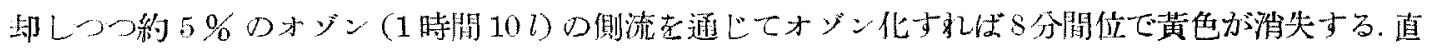

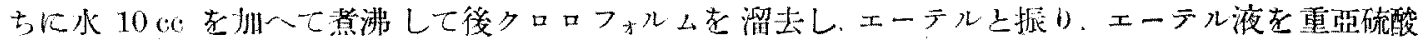

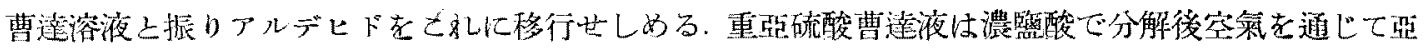

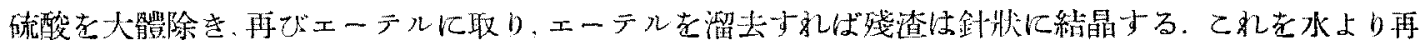

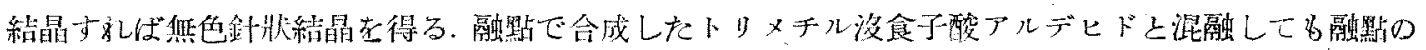
降下方兴昏い。

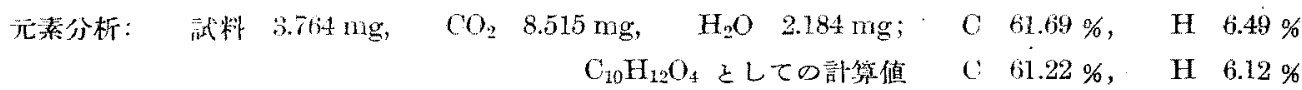

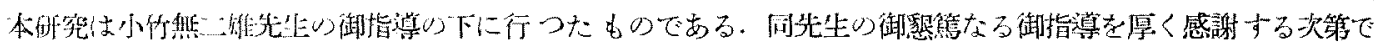
古司。

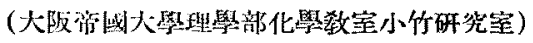

\section{正誤 (報 交)}

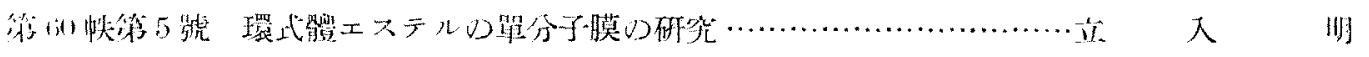

\begin{tabular}{|c|c|c|c|}
\hline it & 储所 & 詔 & 正 \\
\hline$+4 ;$ & 料注 2 们U & (117) & (1917) \\
\hline $4+t j$ & 筷 5 间 & 默線 & 默線は水面を表はす \\
\hline+44 & 新2表，符1 行 & Cetyl palmitate & Ethyl palmitate \\
\hline 50 & t行H & $\mathrm{HaOH}$ & $\mathrm{NaOH}$ \\
\hline
\end{tabular}

